\title{
Lusioersily
}

\section{Validation of large-volume batch solar reactors for the treatment of rainwater in field trials in sub-Saharan Africa}

Reyneke, B., Ndlovu, T., Vincent, M., Martinez-García, A., Polo-Lopez, MI., Fernandez-lbanez, P., Ferrero, G., Khan, S., McGuigan, K. G., \& Khan, W. (2020). Validation of large-volume batch solar reactors for the treatment of rainwater in field trials in sub-Saharan Africa. Science of the Total Environment, 717, 1-10. [137223]. https://doi.org/10.1016/j.scitotenv.2020.137223

Link to publication record in Ulster University Research Portal

\section{Published in:}

Science of the Total Environment

Publication Status:

Published (in print/issue): 15/05/2020

DOI:

10.1016/j.scitotenv.2020.137223

\section{Document Version}

Author Accepted version

\section{General rights}

Copyright for the publications made accessible via Ulster University's Research Portal is retained by the author(s) and / or other copyright owners and it is a condition of accessing these publications that users recognise and abide by the legal requirements associated with these rights.

\section{Take down policy}

The Research Portal is Ulster University's institutional repository that provides access to Ulster's research outputs. Every effort has been made to ensure that content in the Research Portal does not infringe any person's rights, or applicable UK laws. If you discover content in the Research Portal that you believe breaches copyright or violates any law, please contact pure-support@ulster.ac.uk. 

Saharan Africa

B. Reyneke ${ }^{a}$, T. Ndlovu ${ }^{a}$, M.B. Vincent ${ }^{b}$, A. Martinez-Garciac ${ }^{c}$, M.I. Polo-López ${ }^{c}$, P. FernándezIbáñez $^{\mathrm{c}, \mathrm{d}}$, G. Ferrero ${ }^{\mathrm{e}}$, S. Khan ${ }^{f}$, K.G. McGuigan ${ }^{\mathrm{g}}$ and W. Khan ${ }^{\mathrm{a}^{*}}$

a Department of Microbiology, Faculty of Science, Stellenbosch University, Private Bag X1, Stellenbosch, 7602, South Africa.

${ }^{\mathrm{b}}$ Ecosystem Environmental Services S.A., Sant Andreu de Llavaneres, Barcelona, Spain.

c Plataforma Solar de Almeria-CIEMAT, P.O. Box 22, Tabernas, Almería, Spain.

${ }^{\mathrm{d}}$ Nanotechnology and Integrated BioEngineering Centre, School of Engineering, University of Ulster, Newtownabbey, Northern Ireland, United Kingdom.

e IHE Delft Institute for Water Education, Westvest 7, 2611, AX, Delft, the Netherlands.

${ }^{f}$ Faculty of Health Sciences, University of Johannesburg, PO Box 17011, Doornfontein, 2028, South Africa.

${ }^{g}$ Department of Physiology and Medical Physics, Royal College of Surgeons in Ireland, Dublin, Ireland.

Short title: Large-scale SODIS treatment of rainwater

Abbreviations $^{1}$

${ }^{*}$ Corresponding Author: Wesaal Khan; Phone: +27218085804; Fax: +27218085846; Email:

\footnotetext{
${ }^{1}$ ADWG - Australian drinking water guidelines; BDL - below detection limit; CFU - colony forming units; CPC compound parabolic collector; DNA - deoxyribonucleic acid; DWAF - Department of Water Affairs and Forestry; E. coli - Escherichia coli; EMA - ethidium monoazide bromide; EU - European Union; FF - first-flush; HPC - heterotrophic plate count/heterotrophic bacteria; LB - luria bertani; PCA - principle component analysis; PET - polyethylene-terephthalate; PMA - propidium monoazide; PMMA - poly(methyl methacrylate); qPCR - quantitative polymerase chain reaction; RHRW - roof-harvested rainwater; ROS - reactive oxygen species; RWH - rainwater harvesting; SABS - South African Bureau of Standards; SODIS - solar disinfection; UV - ultraviolet radiation; WATERSPOUTT - Water Sustainable PointOf-Use Treatment Technologies; WHO - World Health Organisation; WSP - water safety plan; Zn - zinc.
} 
The efficiency of two large-scale solar reactors [Prototype I (140 L) and II (88 L)] in treating rainwater on-site in a local informal settlement (Site 1) and farming community (Site 2) was assessed. Untreated (Tank 1 and Tank $2 \mathrm{FF}$ ) and treated (Prototype I and II) tank water samples were routinely collected from each site and all the measured physico-chemical parameters, anions and cations were within national and international drinking water guidelines limits. Culture-based analysis indicated that Escherichia coli, total and faecal coliforms, enterococci and heterotrophic bacteria counts exceeded drinking water guideline limits in $61 \%, 100 \%, 45 \%, 24 \%$ and $100 \%$ of the untreated tank water samples collected from both sites. However, an 8 hour solar exposure treatment for both solar reactors was sufficient to reduce these indicator organisms to within drinking water standards, with the exception of the heterotrophic bacteria which exceeded the drinking water guideline limit in $43 \%$ of the samples treated with the Prototype I reactor (1.01 log reduction). Molecular viability analysis subsequently indicated that mean overall reductions of $75 \%$ and $74 \%$ were obtained for the analysed indicator organisms (E. coli and enterococci) and opportunistic pathogens (Klebsiella, Legionella, Pseudomonas, Salmonella and Cryptosporidium oocysts) in the Prototype I and II solar reactors, respectively. The large-scale solar reactor prototypes could thus effectively provide three (88 L Prototype II) to five (144 L Prototype I) people on a daily basis with the basic water requirement for human activities ( $25 \mathrm{~L})$. Additionally, the outlined water safety plan may aid in identifying how and where rainwater harvesting systems should be installed and maintained to ensure the quality of the treated water.

Keywords: Rainwater harvesting; solar disinfection; rainwater quality; sub-Saharan Africa 
The Global Risks Report released for 2019 listed water crises as one of the top ten risks in terms of likelihood (rating of 9; very likely to occur) and impact (rating of 4; severe impact) (Global Risks Report, 2019). The probability of a water crisis risk in sub-Saharan Africa is significantly increased as a high proportion of the population reside in urban informal settlements and rural areas, with limited access to a safe water supply and sanitation infrastructure (Dos Santos et al. 2017). However, as highlighted by Gwenzi and Nyamadzawo (2014) and Emenike et al. (2017), rainwater is considered an under-exploited water source in sub-Saharan Africa and may serve as an effective reserve to improve and encourage equity in water access. Roof-harvested rainwater (RHRW) can however, be contaminated with various chemicals and microorganisms, which may limit its use as a potable water source (Hamilton et al. 2019). While the chemical pollutants have not been directly associated with the incidence of disease, organic debris and faecal matter from animals and birds that have access to the catchment surface, have been identified as the primary sources of microbial contaminants such as Legionella, Klebsiella, Pseudomonas and Cryptosporidium (Hamilton et al. 2019).

Treatment strategies that may be implemented to improve the quality of rainwater include the utilisation of gutter screens or first-flush diverters for the prevention of contaminant entry into the collection tank or post-collection treatment [chemical (e.g. chlorination) and physical treatments (e.g. filtration, solar disinfection (SODIS) and thermal disinfection)] (Hamilton et al. 2019). Although various chemical and physical treatment technologies have been investigated, SODIS is considered a cost-effective treatment method and is recommended by the World Health Organisation (WHO) for the effective reduction of microbial contamination in water sources (Ubomba-Jaswa et al. 2010). In its simplest form, SODIS entails filling a transparent container [usually a $2 \mathrm{~L}$ or $5 \mathrm{~L}$-polyethylene-terephthalate (PET) bottle] with contaminated water and exposing the bottle to direct sunlight for six to eight hours 
(McGuigan et al. 2012). Ultraviolet radiation directly inactivates the microbial contaminants by damaging nucleic acids and leads to the formation of reactive oxygen species (ROS), which react and damage proteins, nucleic acids and membrane lipids (Nelson et al. 2018). The water temperature will also increase as water molecules absorb the UV radiation, which leads to cell membrane damage. The major drawbacks associated with this technique are however, the small volumes of water that can effectively be treated (2 to $5 \mathrm{~L}$ ) and decreased efficiency during overcast weather conditions (up to 48 hours of treatment). Increases in treatment volume and efficiency may then be obtained by employing various modifications (SODIS enhancement technologies) such as solar mirrors (concentrates UV radiation) and larger reactor tubes (increase treatment volume) (Ubomba-Jaswa et al. 2010; McGuigan et al. 2012). As part of the European Union (EU) Horizon 2020 project titled Water Sustainable Point of Use Treatment Technologies (WATERSPOUTT), Polo-López et al. (2019a) investigated various enhancement technologies that may cost-effectively allow for larger volumes of water to be treated using SODIS. Results from the study indicated that the use of a static batch reactor system employing U-type solar mirrors-allowed for the effective treatment of a larger volume (68\% more) of water as compared to the compound parabolic collector (CPC)-type solar mirrors under the same solar exposure conditions (Polo-López et al. 2019a). In a follow-up study, the same research group designed two large-scale solar reactor prototypes (static batch systems with $88 \mathrm{~L}$ and $140 \mathrm{~L}$ treatment volumes, respectively), where multiple poly(methyl methacrylate) (PMMA) reactor tubes were positioned in the centre of Utype solar mirrors (Polo-López et al. 2019b). Preliminary assessment of the solar reactor prototypes, using spiked synthetic rainwater samples and culture-based analysis, indicated that $a \geq 6$ log removal efficiency was obtained for Escherichia coli (E. coli) and Salmonella enteriditis after 1.5 hour natural sunlight exposure, while a 2 hour sunlight exposure was required to achieve the same log reduction for Enterococcus faecalis and Pseudomonas aeruginosa ( $P$. aeruginosa).

The primary aim of the current study was to assess the efficiency of the two newly designed large-scale solar reactor prototypes (Polo-López et al. 2019b) for the treatment of 
RHRW on-site in a local informal settlement (140 L Prototype I) and a rural farming community (88 L Prototype II). The chemical quality of the RHRW before and after solar reactor treatment was routinely assessed by monitoring various physico-chemical parameters (e.g. temperature, $\mathrm{pH}$, and turbidity), anions and cations. Additionally, the removal of traditional indicator organisms (E. coli, total and faecal coliforms, enterococci and heterotrophic bacteria) and selected opportunistic pathogens (Klebsiella spp., Pseudomonas spp. and Salmonella spp.), was assessed using culture-based analysis. Ethidium monoazide bromide quantitative polymerase chain reaction (EMA-qPCR) assays were also used to monitor the reduction efficiency of indicator organisms (E. coli and enterococci) and opportunistic pathogens (Klebsiella spp., Legionella spp., Pseudomonas spp., and Salmonella spp.), while propidium monoazide (PMA) qPCR assays were used to monitor Cryptosporidium oocyst reductions. A water safety plan (WSP) outlining guidelines for the use of rainwater harvesting combined with solar reactor treatment was also implemented.

\section{Materials and methods}

\subsection{Description of large-scale solar reactor prototypes and sampling sites}

Two large-scale solar reactor prototypes were designed and constructed as part of Work Package 1 (WP1) by the WATERSPOUTT research consortium as part of a EU Horizon 2020 project under grant agreement no. 688928 for implementation in South Africa and Uganda. Detailed information on the design and working mechanisms of the systems are outlined in Polo-López et al. (2019b), with the current study focussing on the application of these systems in field trials in South Africa. The Prototype I solar reactor (140 L treatment volume) was installed in Enkanini informal settlement (Site 1; GPS coordinates: 3355'28.1"S 1850'35.8"E) during July 2018 and consisted of three PMMA reactor tubes (200 mm diameter) that were positioned in the centre of a U-type solar mirror (constructed from anodized aluminium). The reactor tubes were positioned at a $34^{\circ}$ angle (equal to the local latitude) and were interconnected by UV-A transparent PMMA tubing (Fig. 1A). The Prototype II solar reactor (88 L 
127 treatment volume) was installed next to a local church building in the Skoolplaas farming community (Site 2; GPS coordinates: 3356'38.5"S 1846'26.3"E) during July 2018 and consisted of the same materials and design as Prototype I, with the exception that eight PMMA tubes (100 mm diameter) were used in the system (Fig. 1B). Additionally, as space was available between the gutter system and the rainwater harvesting $(\mathrm{RWH})$ tank at site 2 , a firstflush (FF) diverter (Superhead $₫$ rainwater filter) was installed to redirect the initial roof run-off during a rain event (Fig. 1B). A detailed description of the sampling sites and system installation is outlined in Appendix A.

\subsection{Sample collection}

For the microbial and chemical analysis of the water produced by the solar reactor prototypes (Fig. 1), an untreated $10 \mathrm{~L}$ sample was collected directly from the RWH tank at each site [hereafter referred to as Tank 1 (Site 1) and Tank 2-FF (Site 2)]. The respective solar reactor prototypes were filled with tank water from the RWH tanks and exposed to direct sunlight for 6 hours (sampling sessions 1 to 8 ) or 8 hours (sampling sessions 9 to 18). Following the solar exposure, $10 \mathrm{~L}$ of each treated sample was collected directly from the solar reactor prototypes ambient UV-A and UV-B radiation] was obtained from the Stellenbosch Weather Services 


\subsection{Chemical analysis}

155

156

157

158

159

160

161

162

163

164

The chemical quality of the untreated and solar reactor treated tank water samples was determined by monitoring cation and anion concentrations and turbidity as described by Strauss et al. (2018). All samples $(n=66)$ were monitored for cations, while representative samples ( $n=22 ; \# 1, \# 7, \# 10, \# 12, \# 15$ and \#18) were monitored for anions and turbidity.

\subsection{Culturing of indicator organisms and opportunistic pathogens}

The microbial quality of the tank water samples collected from sites 1 and 2 were monitored before (untreated) and after solar reactor treatment using various culture-based analyses. Escherichia coli and total coliforms were enumerated simultaneously using membrane filtration as described by Dobrowsky et al. (2015), while enterococci, faecal coliforms and the heterotrophic plate count/bacteria (HPC) were enumerated as outlined in Strauss et al. (2016), with a minor modification; Luria Bertani (LB) agar (Biolab, Merck, South Africa) replaced Reasoner's 2A agar (Oxoid, Hampshire, England) for the enumeration of HPC. For the treated samples (Prototypes I and II) where the HPC were reduced to below the detection limit [BDL; $<1$ colony forming units $(\mathrm{CFU}) / 1 \mathrm{~mL}$, the potential regrowth of bacteria was monitored. Briefly, $20 \mathrm{~mL}$ of each treated sample was stored in a sterile McCartney bottle at room temperature and $100 \mu \mathrm{L}$ of the treated water was spread plated onto LB agar (Biolab, Merck) every 24 hours for a period of 2 days. The plates were then incubated at $37^{\circ} \mathrm{C}$. Additionally, Klebsiella spp., Pseudomonas spp. and Salmonella spp. were enumerated as outlined in Clements et al. (2019), while coliphages were enumerated as outlined by Baker et al. (2003) using E. coli ATCC 13706 as the target bacterial host. All culture-based analyses were performed in duplicate.

\subsection{Tank water concentration, viability treatment and DNA extraction}

The concentration of $1 \mathrm{~L}$ (Site 1 ) and $2 \mathrm{~L}$ (Site 2) samples, EMA treatment and subsequent DNA extractions were performed for each of the samples collected before and after solar 
reactor treatment as outlined in Reyneke et al. (2016). For the molecular quantification of Cryptosporidium spp. within the collected samples, the same methodology was repeated with the exception that a PMA treatment as described by Alonso et al. (2014) was followed.

\subsection{Molecular-based enumeration of indicator organisms and opportunistic pathogens}

Quantitative PCR was performed in order to quantify E. coli, enterococci, Klebsiella spp., Legionella spp., Pseudomonas spp. and Salmonella spp. in all of the collected tank water samples, while Cryptosporidium oocysts were quantified in the samples collected from \#9 to \#15 and \#9 to \#18 for sites 1 and 2, respectively. All qPCR assays were conducted using a LightCycler® 96 (Roche Diagnostics, Risch-Rotkreuz, Switzerland) instrument in combination with the FastStart Essential DNA Green Master Mix (Roche Diagnostics) as outlined in Reyneke et al. (2017), with the primer pairs and cycling parameters presented in Table A1. Standard curves for the respective qPCR assays were generated using the methodology outlined in Reyneke et al. (2017), while the qPCR performance characteristics of the various assays were analysed using the Roche LightCycler® 96 Software Version 1.1. Furthermore, to compensate for the different sample volumes used per site for rainwater concentration [1 $\mathrm{L}$ (Site 1) and $2 \mathrm{~L}$ (Site 2)] the gene copies detected in the samples utilising the qPCR assays cell equivalents (cells or oocysts $/ 100 \mathrm{~mL}$ ) by utilising the number of copies of the target gene present within the target host (Table A1). All final concentrations for qPCR analyses are thus presented as equivalent cells or oocysts $/ 100 \mathrm{~mL}$ original tank water sample.

\subsection{Maintenance of prototype reactors and water safety plan}

201 Following the system installations, workshops were conducted within the respective 202 communities to outline the principle of rainwater harvesting, the working mechanism and 203 operational maintenance of the solar reactors. Information on the domestic activities (i.e. 204 laundry, cleaning, washing, etc.) the treated rainwater could be used for was also provided 
205 (Fig. A3). Exemption from ethical clearance was obtained from the Research Ethics

206 Committee (Humanities) Stellenbosch University (Ethics Reference no.: SU-HSD-004624), as the participating households would not be using the treated water for drinking purposes.

As outlined by the WHO (2004), the most efficient way of consistently ensuring the safety of a drinking water supply is through the utilisation of a WSP (Appendix B), which may be defined as a risk assessment and management approach that monitors the entire water supply process (e.g. collection of RHRW to utilisation of treated tank water by the consumer). The first step in the development of the WSP was to identify all potential hazards/hazardous events that may influence the quality of rainwater during the harvesting process, storage and treatment process (Appendix B), using published literature and personal observations at the respective study sites, during the study period. Additionally, various maintenance and remedial actions were identified to prevent certain water safety hazards (e.g. prevent organic debris from entering the storage tank) or to implement after a hazardous event occurred (e.g. control measure failed and organic debris washed into the storage tank) (Appendix B). Following the identification of the potential hazards, a risk assessment matrix (Appendix C) was compiled that would enable the risk characterisation associated with each hazard/hazardous event and enable the assessment of the various control measures (e.g. maintenance strategies, use of a first-flush diverter system etc.) in eliminating the identified water safety hazards.

\subsection{Statistical analysis}

Statistical analyses were conducted utilising either RStudio (version 1.0.153) or Microsoft Excel ${ }^{\circ}$ Ver. 15.31. Overall differences in sample composition between site 1 and site 2 and the untreated (Tank 1 and Tank 2) and solar reactor treated (Prototype I and II) tank water samples was determined by evaluating all measured physico-chemical, chemical and microbial parameters using the parametric paired $t$-test (significant when $p<0.05$ ). Principle component analysis (PCA) was then used to visualise the correlations between the measured 
231 cations at both sites and identify which cations primarily influenced the sample composition at 232 each site.

\section{Results and Discussion}

3.1 Physico-chemical properties and chemical analysis of the collected tank water samples

The mean ambient UV-A radiation at both sampling sites ranged from $7.16 \mathrm{~W} / \mathrm{m}^{2}(12 / 09 / 2018)$ to $31.29 \mathrm{~W} / \mathrm{m}^{2}(14 / 01 / 2019)$, while the mean ambient UV-B radiation ranged from $1.33 \mathrm{~W} / \mathrm{m}^{2}$ $(12 / 09 / 2018)$ to $4.63 \mathrm{~W} / \mathrm{m}^{2}(14 / 01 / 2019)$ (Table A2). The untreated tank water temperature at site 1 (Tank 1$)$ ranged from $9.0{ }^{\circ} \mathrm{C}(02 / 08 / 2018$ and $15 / 08 / 2018)$ to $24.0{ }^{\circ} \mathrm{C}(28 / 01 / 2019)$, with a mean temperature of $16.3^{\circ} \mathrm{C}$ recorded for all sampling days, while the tank water temperature in the samples collected from the Prototype I solar reactor ranged from $15.5^{\circ} \mathrm{C}$ $(12 / 09 / 2018)$ to $45.0^{\circ} \mathrm{C}(28 / 01 / 2019)$ (mean $\left.28.9{ }^{\circ} \mathrm{C}\right)$. Similarly, the untreated tank water temperature at site 2 (Tank 2-FF) ranged from $10.0{ }^{\circ} \mathrm{C}(15 / 08 / 2018)$ to $26.0{ }^{\circ} \mathrm{C}(25 / 10 / 2018)$ (mean $18.1^{\circ} \mathrm{C}$ ), while the tank water temperature in the samples collected from the Prototype II solar reactor ranged from $18.0^{\circ} \mathrm{C}(12 / 09 / 2018)$ to $46.5^{\circ} \mathrm{C}(28 / 01 / 2019)$ (mean $\left.32.6{ }^{\circ} \mathrm{C}\right)$. dissolved solids and dissolved oxygen) in the collected untreated and prototype treated rainwater samples adhered to the drinking water guideline limits of the South African Department of Water Affairs and Forestry (DWAF) (DWAF, 1996), South African National Standards (SANS) 241 [South African Bureau of Standards (SABS), 2005], Australian Drinking Water Guidelines (ADWG) (NHMRC and NRMMC, 2011) and WHO (2011), with no significant difference $(p>0.05)$ observed for the data collected for the untreated and treated (Tank 1 and Prototype I; Tank 2-FF and Prototype II) tank water samples or between sites 1 and 2 (Tank 1 and 2-FF) (Table A3).

Results for the chemical analyses of the untreated (Tank 1 and Tank 2-FF) and treated 
257 all anions and cations (Table A3) were within the respective drinking water guideline limits 258 [DWAF, 1996; SANS 241 (SABS, 2005); ADWG (NHMRC and NRMMC, 2011); WHO, 2011], with the exception of the mean zinc $(\mathrm{Zn})$ concentration recorded in the samples collected from site 1 [Tank 1 (mean of $3044 \mu \mathrm{g} / \mathrm{L}$ ) and Prototype I (mean of $3061 \mu \mathrm{g} / \mathrm{L}$ )]; which exceeded (albeit not significantly) the DWAF (1996) and ADWG (NHMRC and NRMMC, 2011) limit of $3000 \mu \mathrm{g} / \mathrm{L}$. However, these samples were within the $5000 \mu \mathrm{g} / \mathrm{L}$ SANS 241 (SABS, 2005) limit. The increased $\mathrm{Zn}$ concentrations recorded at site 1 (Tank 1 and Prototype I), in comparison to site 2 (Tank 2-FF and Prototype II), may primarily be attributed to the metal sheeting (e.g. $\mathrm{Zn}$ sheeting) roofing material used to construct the catchment system, as the leaching of metals from metal roofing materials (corrosion during rain events and continuous exposure to sunlight) have been reported to be a major contributor of metal ions in rainwater (Chang et al. 2004; Reyneke et al. 2018). It should be noted, that while the catchment system at site 2 was also constructed from $\mathrm{Zn}$ sheeting roofing material, the entire surface of the catchment system was painted with a weather resistant roof paint (personal communication) which may have limited the leaching of metal ions into the rainwater. Additionally, the first-flush diverter connected to the rainwater tank at site 2 (Tank 2-FF) may have improved the physico-chemical quality of the tank water samples. First-flush diverter systems act as a pre-treatment barrier by redirecting the initial roof run-off water (at the start of a rain event), which is thought to authors concluded that the diversion of the first-flush roof run-off away from the collection tanks may improve the physico-chemical quality of the RHRW. concentrations (Table A3) recorded in the untreated tank water samples to the treated tank water samples (Tank 1 vs Prototype I, Tank 2-FF vs Prototype II) and the tank water samples from each site clustered together (Fig. 2), it was concluded that the solar reactor prototypes 
285 (system components and the treatment mechanism) did not influence the chemical quality of 286 the tank water samples.

\subsection{Removal efficiency of indicator bacteria and opportunistic pathogens}

\subsubsection{Culture-based analysis}

289

290

291

292

293

294

295

296

297

For the untreated tank water samples collected from site 1 (Tank $1 ; n=15$ ), the $E$. coli, faecal coliform, total coliform, enterococci and HPC concentrations exceeded the respective drinking water guideline limits in $67 \%, 73 \%, 100 \%, 20 \%$ and $100 \%$ of the samples, respectively (Table 1). Analysis of the corresponding treated samples (Prototype $\mathrm{I} ; n=15$ ) indicated that the E. coli (> 0.78 log reduction), enterococci (> 3.48 log reduction) and faecal coliform (> 4.08 log reduction) concentrations were reduced to $\mathrm{BDL}(<1 \mathrm{CFU} / 100 \mathrm{~mL})$ in all the collected samples. Total coliforms were reduced to BDL in $63 \%$ of the treated samples collected following a 6 hour solar exposure (\# 1-8) (> 3.94 log reduction), with a mean of 55 CFU/100 mL detected in the samples (37\%) where total coliform counts above the standard were detected. An increase in solar exposure to 8 hours (\# 9-15) resulted in an increased treatment efficiency, as total coliforms were reduced to within the $5 \mathrm{CFU} / 100 \mathrm{~mL}$ DWAF (1996) and $10 \mathrm{CFU} / 100 \mathrm{~mL}$ SANS 241 (SABS, 2005) guideline limits in 100\% of the treated samples (4.66 log reduction). For the HPC analysis, $38 \%$ of the treated samples were reduced to within the drinking water guideline limit of $1.0 \times 10^{4} \mathrm{CFU} / 100 \mathrm{~mL}$ (1.71 log reduction) after a 6 hour solar exposure [mean of $2.4 \times 10^{4} \mathrm{CFU} / 100 \mathrm{~mL}$ detected in the remaining $63 \%$ samples $(1.21 \mathrm{log}$ reduction)], while $57 \%$ of the treated samples were reduced to within the guideline limit $(2.08$ log reduction) after an 8 hour solar exposure [mean of $2.7 \times 10^{4} \mathrm{CFU} / 100 \mathrm{~mL}$ detected in the remaining $43 \%$ of samples (1.01 log reduction)] (Fig. A6).

For the untreated tank water samples collected from site 2 (Tank 2-FF; $n=18$ ), the E. coli, faecal coliform, total coliform, enterococci and HPC concentrations exceeded the respective drinking water guideline limits in $56 \%, 22 \%, 100 \%, 28 \%$ and $100 \%$ of the samples, respectively (Table 1). Analysis of the corresponding treated samples (Prototype II; $n=18$ ) 
311 indicated that the E. coli (> 0.48 log reduction), enterococci ( $>3.34$ log reduction) and faecal 312 coliform (> 3.04 log reduction) concentrations were reduced to BDL $(<1 \mathrm{CFU} / 100 \mathrm{~mL})$ in all collected samples, while total coliforms were reduced to within the $5 \mathrm{CFU} / 100 \mathrm{~mL}$ DWAF (1996) and 10 CFU/100 mL SANS 241 (SABS, 2005) guideline limits (3.85 log reduction). Heterotrophic bacteria were then reduced to within the $1.0 \times 10^{4} \mathrm{CFU} / 100 \mathrm{~mL}$ DWAF (1996) drinking water guideline limit in $88 \%$ of the treated samples (mean of $4.6 \times 10^{3} \mathrm{CFU} / 100 \mathrm{~mL}$ recorded) after a 6 hour solar exposure (\# 1-8) (2.11 log reduction), with a mean of $1.8 \times 10^{4} \mathrm{CFU} / 100 \mathrm{~mL}$ detected in the samples $(12 \%)$ where HPC concentrations above the standard were detected. In comparison, $100 \%$ of the treated samples were reduced to within the $1.0 \times 10^{4} \mathrm{CFU} / 100 \mathrm{~mL}$ drinking water guideline limit after an 8 hour solar exposure (\# 918) ( $\geq 2.02$ log reduction; Fig. A6).

Klebsiella spp. were detected in $100 \%$ (mean concentration of $1.9 \times 10^{4} \mathrm{CFU} / 100 \mathrm{~mL}$ ) and Salmonella spp. in $60 \%$ (mean concentration of $6.3 \times 10^{3} \mathrm{CFU} / 100 \mathrm{~mL}$ ) of the untreated BDL (> 4.28 and $>3.8$ log reduction, respectively) following treatment using the Prototype I solar reactor (Table 1). Klebsiella spp. were also detected in $17 \%$ (mean concentration of $8.0 \times 10^{2} \mathrm{CFU} / 100 \mathrm{~mL}$ ) and Salmonella spp. in $6 \%$ (mean concentration of $1.0 \times 10^{3} \mathrm{CFU} / 100 \mathrm{~mL}$ ) of the untreated rainwater samples collected from site 2 (Tank 2-FF), with both organisms reduced to $\mathrm{BDL}(>2.9$ and $>3$ log reduction, respectively) following treatment using the Prototype II solar reactor (Table 1). Pseudomonas spp. and coliphages were not detected in any of the rainwater samples collected from sites 1 and 2 .

Although numerous studies have investigated the use of SODIS to treat contaminated water, varying degrees of treatment efficiency ( 0.46 to $>6$ log reductions in bacteria) have been reported depending on experimental design (McGuigan et al. 2012; Hamilton et al. 2019). However, a limitation of SODIS which has consistently been highlighted by these investigators is the small treatment volume (2 to $5 \mathrm{~L})$. Ubomba-Jaswa et al. (2010) investigated the use of a $25 \mathrm{~L}$ SODIS reactor (methacrylate tube) situated inside a CPC and reported on the complete inactivation of $E$. coli, even during unfavourable weather conditions (cloudy with 
339 low solar intensity). Polo- López et al. (2019a) then expanded on this research and 340 investigated cost-effective SODIS enhancement strategies that would enable the treatment of larger volumes of water ( $32 \mathrm{~L}$ and $54 \mathrm{~L}$ ), with the results obtained leading to the design of the large-scale solar reactor prototypes (Prototype I and II) assessed in the current study. The treatment efficiency of the Prototype I and II solar reactors was also assessed by Polo-López et al. (2019b) under controlled conditions, by spiking synthetic rainwater with laboratory strains of E. coli, enterococci, Salmonella and Pseudomonas $\left(10^{5}-10^{6} \mathrm{CFU} / \mathrm{mL}\right.$ bacterial cells) using a 6 hour solar exposure treatment time. $A \geq 6 \log$ reduction of all the test bacteria was obtained, with the system classified as "highly protective ( $\geq 4$ log reduction)" against bacteria according to the WHO (2016) household water treatment technology performance criteria. In comparison, results from the current study, for both solar reactor prototypes, during a 6 hour solar exposure treatment, indicated that $\geq 2.54$ log reduction was obtained when monitoring the removal of enterococci, faecal and total coliforms, while mean log reductions of $\geq 1.21 \mathrm{log}$ were obtained for the removal of HPC. Based on these results, the 6 hour solar exposure "protective" classification against bacteria. The Polo-López et al. (2019b) study was however, conducted in a hot arid climate (Tabernas Dessert, Almería, Spain) with a mean UV radiation of $28.31 \mathrm{~W} / \mathrm{m}^{2} / \mathrm{h}$ recorded during the 6 hour treatment trials, while the field trials of the systems in the current study were conducted in a moderate Mediterranean climate (Stellenbosch, Western Cape, South Africa), where a mean UV radiation of $20.82 \mathrm{~W} / \mathrm{m}^{2} / \mathrm{h}$ was recorded during the 6 hour treatment trials (Table A2).

The treatment time in the current study was subsequently increased to 8 hours (Site 1: \#9-15; Site 2: \#9-18) in order to increase the overall UV dose (mean UV radiation of $24.72 \mathrm{~W} / \mathrm{m}^{2} / \mathrm{h}$ was recorded from \#9-18). For both prototypes a $\geq 3.44$ log reduction was subsequently obtained when monitoring the removal of enterococci, faecal and total coliforms, while the mean log reductions for the removal of HPC increased to $\geq 2.02 \log$. Based on the observed treatment efficiencies obtained using the Prototype I and II solar reactors in the current study ( 8 hour treatment), the prototypes may be classified as "protective ( $\geq 2$ log 
reduction)", for the removal of bacteria in the tank water (WHO, 2016). More importantly, culture-based analysis indicated that both treatment systems were able to produce water that adhered to the microbial parameters as stipulated in the respective drinking water guidelines [DWAF, 1996; SANS 241 (SABS, 2005); ADWG (NHMRC and NRMMC, 2011); WHO, 2011], with lower indicator organism counts recorded in the tank water samples collected from site 2 , where the first-flush diverter system was installed. The treated water collected from the largescale solar reactor prototypes could however, only be stored for a maximum of 24 hours, as microbial re-growth occurred after this point.

\subsubsection{Molecular-based analysis}

The performance characteristics of the respective qPCR assays are provided in Table A4. Results obtained using EMA-qPCR indicated that an overall mean decrease of $83.76 \%(0.79$ log reduction) in intact E. coli cells was recorded after treatment using Prototype I, while an overall mean decrease of $82.76 \%$ ( 0.76 log reduction) was recorded after treatment for Prototype II (Fig. 3). Similarly, intact enterococci cells decreased by a mean of $91.68 \%$ (1.08 log reduction) after treatment using Prototype I, while an $84.89 \%$ (0.82 log reduction) mean decrease was recorded after treatment using Prototype II (Fig. 3). In comparison, quantification of intact Klebsiella cells indicated that this genus was more resistant to the solar reactor treatment as mean decreases of $62.44 \%$ (0.43 log reduction) and $60.42 \%$ ( $0.40 \mathrm{log}$ reduction) were recorded after treatment using Prototype I and II, respectively (Fig. 3). Similarly, intact Legionella cells decreased by $68.61 \%$ ( 0.50 log reduction) after treatment using Prototype I and by $63.77 \%$ (0.44 log reduction) after treatment using Prototype II (Fig. 3). Overall mean decreases in intact Pseudomonas cells of $79.09 \%$ (0.68 log reduction) and 87.50\% (0.90 log reduction) were recorded after treatment using Prototype I and II, respectively, while Salmonella cells decreased by $78.36 \%$ ( 0.66 log reduction) after treatment using Prototype I and 67.82\% (0.49 log reduction) after treatment with Prototype II (Fig. 3). Lastly, PMA-qPCR analysis indicated that Cryptosporidium oocysts decreased by $57.14 \%$ 

log reduction) was recorded after treatment using Prototype II (Fig. 3). solar reactors reduced the opportunistic pathogens by $74.43 \%$. This discrepancy in the observed treatment efficiency in comparison to the results obtained using culture-based analysis, may be attributed to EMA-qPCR and PMA-qPCR detecting viable but non culturable (VBNC) cells within the water samples (Fittipaldi et al. 2012; Mansi et al. 2014). It has been reported that certain opportunistic pathogens (e.g. Legionella pneumophila and $P$. aeruginosa) can enter a VBNC state in which they are not detectable using standard culture-based analysis but are still viable and retain their virulence (Mansi et al. 2014). Moreover, these VBNC microorganisms may regain their ability to be cultured under favourable conditions, which corresponds to the observed bacterial re-growth observed after 24 hours (culture-based analysis). Strauss et al. (2019) then applied Illumina next-generation sequencing coupled with EMA viability treatment to identify the primary pathogenic or opportunistic pathogenic genera, capable of surviving SODIS-CPC treatment in a 10.6 L CPCreactor (Strauss et al. 2019). Results from the study indicated that intact and potentially viable bacterial cells belonging to 11 different bacterial genera (e.g. Acinetobacter, Campylobacter, Legionella, Mycobacterium and Pseudomonas amongst others) were detected in the SODISCPC treated tank water. Monitoring for the presence of VBNC microorganisms following water treatment is thus essential as these VBNC bacteria still pose a health risk as they are potentially infectious (Mansi et al. 2014).

While the survival of the Cryptosporidium oocysts after SODIS treatment using the solar reactor prototypes, may be attributed to the resilient nature of the oocyst wall (Hamilton et al. 2018), the ability of the opportunistic pathogenic bacteria (Pseudomonas spp., Salmonella spp., Legionella spp. and Klebsiella spp.) to survive large-scale solar-based disinfection strategies has been attributed to their ability to initiate various stress-response mechanisms and switch to a more tolerant phenotype upon exposure to environmental stressors, such as temperature and UV exposure (Jones, 1997; Fux et al. 2005). These stress- 
responses may include the production of heat shock proteins and the initiation of DNA repair mechanisms, amongst others (Fields et al. 2002; Breidenstein et al. 2011). For example, Srivastava et al. (2008) indicated that the overexpression of the sigma factor algT, protects Pseudomonas spp. from heat stress and allows these organisms to persist during unfavourable conditions, while DNA repair mechanisms may be initiated in response to UVinduced DNA damage, through the activation of the SOS-regulon (upregulation of recA and lexA) or the photolyase enzyme (Zenoff et al. 2006). Similarly, Bojer et al. (2010) attributed the heat resistance of $K$. pneumoniae to the $c / p K$ genetic marker, which has been shown to correlate positively with thermotolerant phenotypes observed among clinical Klebsiella isolates. Microorganisms have also been reported to produce pigments or structures that may enable their survival under unfavourable conditions, as has been reported for $P$. aeruginosa where the production of pyocyanin has been hypothesised to protect $P$. aeruginosa from oxidative stress (inactivation mechanism of SODIS) (Hendiani et al. 2019). It is thus evident that microorganisms may employ numerous strategies to survive disinfection treatment and that additional treatment barriers may be required to reduce the survival of these target pathogens within water treatment systems. These strategies may include the addition of a cost-effective filtration system as a pre-treatment strategy to reduce microbial load entering the large-scale solar reactor prototypes (Hamilton et al. 2019).

\subsection{Water safety plan and operational sustainability of the systems}

As numerous factors may influence the quality of RHRW during the harvesting and/or treatment process, a WSP (Appendix B) for the utilisation of rainwater harvesting in combination with the large-scale solar reactor prototypes was developed. As the WSP was developed concurrently with the monitoring of the large-scale solar reactor prototypes during the field trials, the effectiveness of the various control measures was assessed by comparing site 1 with site 2, as these sites were located in two distinct settings that could be influenced by different anthropogenic activities and potential pollution sources as outlined in Appendix A. 

at sites 1 and 2, indicated that the external hazards at site 1 (informal settlement) posed a greater risk of contamination. The increased risk was primarily attributed to the influence of potential pollution sources present near the catchment system (e.g. garbage disposal site, surface run-off), tree branches obstructing a section of the conveyance system, organic debris (e.g. dust/soil dispersed from the dirt pathway, leaves from the tree) within the conveyance system and corrosion of the metal sheeting catchment system. Correspondingly, chemical and microbial analysis of the untreated tank water samples collected from sites 1 and 2 revealed that the untreated tank water collected from site 1 had higher levels of chemical contaminants (e.g. cations) and microbial contaminants in comparison to site 2. For example, the concentration of HPC was $0.72 \log \left[3.50 \times 10^{5} \mathrm{CFU} / 100 \mathrm{~mL}\right.$ (Tank 1) vs $6.90 \times 10^{4}$ CFU/100 mL (Tank 2-FF)] greater in the untreated tank water samples from site 1 (Tank 1), in comparison to site 2 (Tank 2-FF).

The improved tank water quality at site 2 may also be attributed to the efficiency of the implemented control measures at this site. The catchment surface at site 2 was painted with a weather resistant roof paint that may have reduced the leaching of metal contaminants into the collected tank water. Additionally, due to space availability a first-flush diverter was connected between the catchment system and Tank 2-FF, which served as a control measure to reduce the introduction of organic debris into the collection tank. However, the efficiency of a first-flush diverter is dependent on the maintenance of the system, which entailed cleaning/emptying the first-flush diverter after each rain event. The quality of RHRW collected from site 1 may then be improved by removing the obstructing tree branches (source of organic debris), implementing a regular gutter cleaning regime, installing a gutter screen at the inlet of the RWH tank (due to space limitation a first-flush diverter could not be connected to the current catchment system) and replacing the corroded metal sheeting on the catchment system or painting the catchment system with a weather resistant roof paint.

As previously indicated, workshops were conducted with participating households within the respective communities to outline the operational maintenance of the large-scale 
solar reactor prototypes and rainwater harvesting systems (Fig. A3). Subsequent monitoring of the operational sustainability of the solar reactor prototypes at both sites indicated that system maintenance was limited to cleaning the surface of the PMMA reactor tubes (prevent dust accumulation that will influence UV transmittance), with no system components needing replacement during the study period. The robustness of system components therefore also needs to be taken into consideration when designing water treatment systems for use in rural areas and informal settlements, where replacement components may not be readily available. During the study period, households who had access to the treated tank water (Prototype I and II) at sites 1 (13 households) and site 2 (5 households), primarily reported using the treated tank water for domestic activities such as cleaning of their homes, laundry and washing.

As noted by Mahmud et al. (2007), the aim of a WSP for small community water supplies should be to achieve an overall and sustained reduction in microbial contaminants/sanitary risks, rather than aim for the complete removal of microbial contaminants. The WSP outlined in the current study thus serves to reduce the contamination of RHRW by reducing "preventable contaminant entry" (e.g. organic debris and faecal matter containing an increased microbial load from washing into the storage tank) into the storage tank, whereafter treatment with the large-scale solar reactor prototypes may further reduce the microbial contaminants to within drinking water standards.

\section{Conclusions}

The physico-chemical and chemical quality of the Tank 1 and 2-FF and Prototype I and II treated rainwater samples adhered to the respective drinking water guidelines, with an improvement in quality observed at site 2 where the first-flush diverter was installed. Lower indicator bacterial counts were also recorded in the tank water samples collected from site 2 (Tank 2-FF and Prototype II) where the first-flush diverter was installed and fewer hazards were identified that may influence the tank water quality (WSP), in comparison to site 1 (Tank 1 and Prototype I). The installation of a first-flush diverter system may thus serve as an inexpensive pre-treatment strategy that may improve the overall quality of RHRW, while the 
502 establishment of a WSP may aid in identifying potential hazards/hazardous events that may

503 influence water safety.

Although both reactor prototypes were able to significantly improve the microbial

505 quality of the tank water after an 8 hour solar treatment, HPC exceeding the DWAF (1996)

506 drinking water guideline limit were recorded in $43 \%$ of the Prototype I treated samples.

507 Nevertheless, a mean 1.01 log reduction in heterotrophic bacteria was recorded for these

508 samples, which would decrease the health risk associated with using the treated rainwater (in

509 comparison to the utilisation of untreated rainwater). Results from the EMA-qPCR and PMA-

510 qPCR analysis indicated that E. coli, enterococci, Klebsiella spp., Legionella spp.,

511 Pseudomonas spp., Salmonella spp. and Cryptosporidium oocysts were reduced by $74.43 \%$

512 in both reactor prototypes. While molecular analysis indicated that the target organisms in the

513 treated rainwater samples were not reduced to below the detection limit, based on national

514 and international drinking water guidelines, the large-scale solar reactor prototypes used in

515 the current study may effectively treat rainwater to within drinking water standards. The $88 \mathrm{~L}$

516 and $140 \mathrm{~L}$ solar reactor prototype treatment systems may thus provide a viable water provision

517 solution for the inhabitants of rural areas and urban informal settlements in sub-Saharan

518 Africa.

519 Conflicts of interests

520 The authors have no conflicts to declare.

521 Acknowledgements

522 This project has received funding from the European Union's Horizon 2020 Research and

523 Innovation Program under grant agreement no. 688928 (WATERSPOUTT H2020-Water-5c). 
525 Alonso, J.L., Amorós, I., Guy, R.A., 2014. Quantification of viable Giardia cysts and 526 Cryptosporidium oocysts in wastewater using propidium monoazide quantitative real-time 527 PCR. Parasitol. Res. 113, 2671-2678. https://doi.org/10.1007/s00436-014-3922-9.

528 Baker, W.P., Leyva, K.J., Klotz, P., Wellington, R.R., 2003. Investigation of bacteriophage as 529 indicators of fecal pollution in urban water samples. Journal of the Arizona-Nevada Academy 530 of Science. 36, 1-4. https://www.jstor.org/stable/40022384.

531 Bojer, M.S., Struve, C., Ingmer, H., Hansen, D.S., Krogfelt, K.A., 2010. Heat resistance mediated by a new plasmid encoded Clp ATPase, ClpK, as a possible novel mechanism for nosocomial persistence of Klebsiella pneumoniae. PLoS ONE. 5, e15467. https://doi.org/10.1371/journal.pone.0015467.

Breidenstein, E.B.M., De La Fuente-Núñez, C., Hancock, R.E.W., 2011. Pseudomonas aeruginosa: all roads lead to resistance. Trends Microbiol. 19, 419-426. https://doi.org/10.1016/j.tim.2011.04.005.

Chang, M., McBroom, M.W., Beasley, R.S., 2004. Roofing as a source of non-point water pollution. J. Environ. Manage. 73, 307-315. https://doi.org/10.1016/j.jenvman.2004.06.014.

Clements, T.L., Reyneke, B., Strauss, A., Khan, W., 2019. Persistence of viable bacteria in solar pasteurised harvested rainwater. Water Air Soil Poll. 230, 130. http://dx.doi.org/10.1007/s11270-019-4184-z.

Department of Water Affairs and Forestry (DWAF)., 1996. South African Water Quality Guidelines $2^{\text {nd }}$ ed. Volume 1: Domestic Water Use. Pretoria, South Africa: CSIR Environmental Services. ISBN 0-7988-5338-7.

546 Dobrowsky, P.H., Lombard, M., Cloete, W.J., Saayman, M., Cloete, T.E., Carstens, M., Khan, 547 S., Khan, W., 2015. Efficiency of microfiltration systems for the removal of bacterial and viral 
548 contaminants from surface and rainwater. Water Air Soil Pollut. 226, 33. 549 https://doi.org/10.1007/s11270-015-2317-6.

550 Dos Santos, S., Adams, E.A., Neville, G., Wada, Y., De Sherbinin, A., Mullin Bernhardt, E., 551 Adamo, S.B., 2017. Urban growth and water access in sub-Saharan Africa: progress, 552 challenges, and emerging research directions. Sci. Total Environ. 607-608, 497-508. 553 https://doi.org/10.1016/j.scitotenv.2017.06.157.

554 Emenike, C.P., Tenebe, I.T., Omole, D.O., Ngene, B.U., Oniemayin, B.I., Maxwell, O., Onoka, 555 B.I., 2017. Accessing safe drinking water in sub-Saharan Africa: Issues and challenges in 556 South-West Nigeria. Sustain. Cities $\quad$ Soc. $30, \quad$ 263-272. 557 https://doi.org/10.1016/j.scs.2017.01.005.

558 Fields, B.S., Benson, R.F., Besser, R.E., 2002. Legionella and Legionnaires' disease: 25 years 559 of investigation. Clin. Microbiol. Rev. 15, 506-526. https://doi.org/10.1128/CMR.15.3.506$560 \quad 526.2002$.

561 Fittipaldi, M., Nocker, A., Codony, F., 2012. Progress in understanding preferential detection 562 of live cells using viability dyes in combination with DNA amplification. J. Microbiol. Methods. 563 91, 276-289. https://doi.org/10.1016/j.mimet.2012.08.007.

564 Fux, C.A., Costerton, J.W., Stewart, P.S., Stoodley, P., 2005. Survival strategies of infectious 565 biofilms. Trends Microbiol. 13, 34-40. https://doi.org/10.1016/j.tim.2004.11.010.

566 Gikas, G.D., Tsihrintzis, V.A., 2012. Assessment of water quality of first-flush roof runoff and 567 harvested rainwater. J. Hydrol. 466-467, 115-126. 568 https://doi.org/10.1016/j.jhydrol.2012.08.020.

569 Global Risks Report., 2019. The Global Risks Report 2019 14th Edition. Available: 570 http://www3.weforum.org/docs/WEF_Global_Risks_Report_2019.pdf. [2019, February 10]. 
571 Gwenzi, W., Nyamadzawo, G., 2014. Hydrological impacts of urbanization and urban roof

572 water harvesting in water-limited catchments: a review. Environ. Process. 1, 573-593.

573 https://doi.org/10.1007/s40710-014-0037-3.

574 Hamilton, K.A., Waso, M., Reyneke, B., Saeidi, N., Levine, A., Lalancette, C., Besner, M-C., 575 Khan, W., Ahmed, W., 2018. Cryptosporidium and Giardia in wastewater and surface water 576 environments. J Environ Qual. 47, 1006-1023. https://doi.org/10.2134/jeq2018.04.0132.

577 Hamilton, K.A., Reyneke, B., Waso, M., Clements, T.L., Ndlovu, T., Khan, W., Digiovanni, K., 578 Rakestraw, E., Montalto, F., Haas, C.N. Ahmed, W., 2019. A global review of the 579 microbiological quality and potential health risks associated with roof-harvested rainwater 580 tanks. Npj Clean Water. 2, 7. https://doi.org/10.1038/s41545-019-0030-5.

581 Hendiani, S., Pornour, M., Kashef, N., 2019. Quorum-sensing-regulated virulence factors in 582 Pseudomonas aeruginosa are affected by sub-lethal photodynamic inactivation. Photodiagn. 583 Photodyn. 26, 8-12. https://doi.org/10.1016/j.pdpdt.2019.02.010. Jones, K., 1997. Strategies for survival. In: Coliforms and E. coli. Problem or solution? D. Kay \& C. Fricker, Eds. Cambridge, UK: The Royal Society of Chemistry.

Mahmud, S.G., Abu Jafar Shamsuddin, S., Feroze Ahmed, M., Davison, A., Deere, D., Howard, G., 2007. Development and implementation of water safety plans for small water supplies in Bangladesh: benefits and lessons learned. J. Water Health. 5, 585-597. https://doi.org/10.2166/wh.2007.045.

590 Mansi, A., Amori, I., Marchesi, I., Marcelloni, A.M., Proietto, A.R., Ferranti, G., Magini, V., 591 Valeriani, F., Borella, P., 2014. Legionella spp. survival after different disinfection procedures: 592 Comparison between conventional culture, qPCR and EMA-qPCR. Microchem. J. 112, 65-69. https://doi.org/10.1016/j.microc.2013.09.017. 
594 McGuigan, K.G., Conroy, R.M., Mosler, H., Du Preez, M., Ubomba-Jaswa, E., Fernandez595 Ibañez, P., 2012. Solar water disinfection (SODIS): a review from bench-top to roof-top. J. 596 Hazard. Mater. 235-236, 29-46. https://doi.org/10.1016/j.jhazmat.2012.07.053.

597 Nelson, K.L., Boehm, A.B., Davies-Colley, R.J., Dodd, M.C., Kohn, T., Linden, K.G., Liu, Y., 598 Maraccini, P.A., McNeill, K., Mitch, W.A., Nguyen, T.H., Parker, K.M., Rodriguez, R.A., 599 Sassoubre, L.M., Silverman, A.I., Wigginton, K.R., Zepp, R.G., 2018. Sunlight-mediated 600 inactivation of health-relevant microorganisms in water: a review of mechanisms and 601 modelling approaches. Environ. Sci.: Proc. Imp. 20, 1089. 602 https://doi.org/10.1039/c8em00047f.

603

604

605

606

607

608

609

610

611

612

613

614

615

616

NHMRC and NRMMC (ADWG)., 2011. Australian drinking water guidelines Paper 6 National Water Quality Management Strategy. National Health and Medical Research Council, National Resource Management Ministerial Council Commonwealth of Australia, Canberra.

Reyneke, B., Dobrowsky, P.H., Ndlovu, T., Khan, S., Khan, W., 2016. EMA-qPCR to monitor the efficiency of a closed-coupled solar pasteurization system in reducing Legionella contamination of roof-harvested rainwater. Sci. Total Environ. 553, 662-670. https://doi.org/10.1016/j.scitotenv.2016.02.108.

Reyneke, B., Ndlovu, T., Khan, S., Khan, W., 2017. Comparison of EMA-, PMA- and DNase qPCR for the determination of microbial cell viability. Appl. Microbiol. Biotechnol. 101, 73717383. https://doi.org/10.1007/s00253-017-8471-6.

Reyneke, B., Cloete, T.E., Khan, S., Khan, W., 2018. Rainwater harvesting solar pasteurization treatment systems for the provision of an alternative water source in peri-urban informal settlements. Environ. Sci: Water Res. Technol. 4, 291-302. https://doi.org/10.1039/c7ew00392g. 
617 Sánchez, A.S., Cohim, E., Kalid, R.A., 2015. A review on physicochemical and microbiological 618 contamination of roof-harvested rainwater in urban areas. Sustainability of Water Quality and 619 Ecology. 6, 119-137. https://doi.org/10.1016/j.swaqe.2015.04.002.

620 South African Bureau of Standards (SABS). 2005. South African National Standards (SANS) 621 241: In Drinking water quality management guide for water services authorities. $6^{\text {th }}$ ed. 622 Annexure 1. ISBN 0-626-17752-9. high temperature on Pseudomonas putida NBRI0987 biofilm formation and expression of stress sigma factor RpoS. Curr. Microbiol. 56, 453-457. https://doi.org/10.1007/s00284-0089105-0.

Strauss A., Dobrowsky P.H., Ndlovu T., Reyneke B., Khan W., 2016. Comparative analysis of solar pasteurization versus solar disinfection for the treatment of harvested rainwater. BMC Microbiol. 16, 289. https://doi.org/10.1186/s12866-016-0909-y.

630 Strauss A., Reyneke B., Waso M., Khan W., 2018. Compound parabolic collector solar 631 disinfection system for the treatment of harvested rainwater. Environ. Sci.: Water Res. 632 Technol. 4, 976-991. https://doi.org/10.1039/C8EW00152A.

Strauss A., Reyneke B., Waso M., Ndlovu T., Brink C., Khan S., Khan W., 2019. EMAamplicon-based taxonomic characterisation of the viable bacterial community present in untreated and SODIS treated roof-harvested rainwater. Environ. Sci.: Water Res. Technol. 5, 91-101. https://doi.org/10.1039/c8ew00613j.

Ubomba-Jaswa, E., Fernández-lbáñez, P., Navntoft, C., Polo-López, M.I., McGuigan, K., 2010. Investigating the microbial inactivation efficiency of a $25 \mathrm{~L}$ batch solar disinfection (SODIS) reactor enhanced with a compound parabolic collector (CPC) for household use. J. Chem. Tech. Biotech. 85, 1028-1037. https://doi.org/10.1002/jctb.2398. 
641 Waso, M., Khan, S., Khan, W., 2018. Microbial source tracking markers associated with 642 domestic rainwater harvesting systems: correlation to indicator organisms. Environ. Res. 161, 643 446-455. https://doi.org/10.1016/j.envres.2017.11.043.

644 World Health Organisation (WHO)., 2004. Guidelines for drinking-water quality. Rev. $3^{\text {rd }}$ ed. 645 World Health Organisation. Geneva, Switzerland: WHO Press. ISBN: 92-4-154638-7.

646 World Health Organisation (WHO)., 2011. Guidelines for drinking-water quality. Rev. $4^{\text {th }}$ ed. 647 World Health Organisation. Geneva, Switzerland: WHO Press. ISBN: 978-92-4-154815-1.

648 World Health Organisation (WHO)., 2016. Results of round 1 of the WHO international scheme 649 to evaluate household water treatment technologies. World Health Organisation. 650 https://apps.who.int/iris/handle/10665/204284.

651 Zenoff, V.F., Siñeriz, F., Farías, M.E., 2006. Diverse responses to UV-B radiation and repair 652 mechanisms of bacteria isolated from high-altitude aquatic environments. Appl. Environ. 653 Microbiol. 72, 7857-7863. https://doi.org/10.1128/AEM.01333-06.

654

655

656

657

658

659

660

661 
Table 1 Frequency of detection and mean concentrations (CFU/100 mL) of indicator organisms

663 and target bacterial pathogens in the tank water samples collected from sites 1 and 2 .

\begin{tabular}{|c|c|c|c|c|}
\hline \multirow[b]{2}{*}{ Organism } & \multicolumn{2}{|c|}{ Site 1} & \multicolumn{2}{|c|}{ Site 2} \\
\hline & $\begin{array}{l}\text { Tank 1 } \\
(n=15)\end{array}$ & $\begin{array}{c}\text { Prototype I } \\
(n=15)\end{array}$ & $\begin{array}{l}\text { Tank 2-FF } \\
(n=18)\end{array}$ & $\begin{array}{l}\text { Prototype II } \\
\quad(n=18)\end{array}$ \\
\hline E. coli & $\begin{array}{l}67 \% \\
(6)\end{array}$ & BDL & $\begin{array}{l}51 \% \\
(3)\end{array}$ & BDL \\
\hline Total coliforms & $\begin{array}{c}100 \% \\
\left(1.5 \times 10^{4}\right)\end{array}$ & $\begin{array}{l}27 \% \\
(42)\end{array}$ & $\begin{array}{c}100 \% \\
\left(1.0 \times 10^{3}\right)\end{array}$ & $\begin{array}{c}11 \% \\
(2)\end{array}$ \\
\hline Enterococci & $\begin{array}{c}20 \% \\
\left(3.0 \times 10^{3}\right)\end{array}$ & $\mathrm{BDL}$ & $\begin{array}{c}28 \% \\
\left(2.2 \times 10^{3}\right)\end{array}$ & $\mathrm{BDL}$ \\
\hline Faecal coliforms & $\begin{array}{c}73 \% \\
\left(1.2 \times 10^{4}\right)\end{array}$ & $\mathrm{BDL}$ & $\begin{array}{c}22 \% \\
\left(1.1 \times 10^{3}\right)\end{array}$ & $\mathrm{BDL}$ \\
\hline $\begin{array}{l}\text { Heterotrophic } \\
\text { bacteria }\end{array}$ & $\begin{array}{c}100 \% \\
\left(3.5 \times 10^{5}\right)\end{array}$ & $\begin{array}{c}50 \% \\
\left(1.8 \times 10^{4}\right)\end{array}$ & $\begin{array}{c}100 \% \\
\left(6.9 \times 10^{4}\right)\end{array}$ & $\begin{array}{c}86 \% \\
\left(6.5 \times 10^{3}\right)\end{array}$ \\
\hline Klebsiella spp. & $\begin{array}{c}100 \% \\
\left(1.9 \times 10^{4}\right)\end{array}$ & $\mathrm{BDL}$ & $\begin{array}{c}17 \% \\
\left(8.0 \times 10^{2}\right)\end{array}$ & $\mathrm{BDL}$ \\
\hline Pseudomonas spp. & ND & ND & ND & ND \\
\hline Salmonella spp. & $\begin{array}{c}60 \% \\
\left(6.3 \times 10^{3}\right)\end{array}$ & BDL & $\begin{array}{c}6 \% \\
\left(1.0 \times 10^{3}\right)\end{array}$ & BDL \\
\hline $\begin{array}{l}\text { Coliphages } \\
\text { (PFU/mL) }\end{array}$ & ND & ND & ND & ND \\
\hline
\end{tabular}

664 BDL - below detection limit; ND - not detected; PFU - plaque forming units

665

666

667

668

669

670

671

672

673

674 


\section{Figure Legends:}

676 Fig. 1. (A) The Prototype I (140 L) solar reactor installed at Site 1. (B) The Prototype II (88 L) 677 solar reactor installed at Site 2. The red arrow indicates the first-flush diverter which was 678 connected to Tank 2-FF.

679 Fig. 2. Principle component analysis of the cations affecting the tank water quality for site 1 680 (Tank 1 and Prototype I) and 2 (Tank 2-FF and Prototype II). The directionality of the arrows 681 indicate the correlation (same = positive; opposite $=$ negative) between the different variables 682 and illustrate the predominant variables best describing the collected tank water samples.

683 Fig. 3. Box and whiskers plot illustrating the distribution of the intact cells or oocysts/100 $\mathrm{mL}$ 684 recorded for each of the target organisms using EMA-qPCR (E. coli, enterococci, Klebsiella 685 spp., Legionella spp., Pseudomonas spp. and Salmonella spp.) and PMA-qPCR 686 (Cryptosporidum oocysts) in the tank water samples collected from (A) site 1 and (B) site 2. 687 The whiskers at the end of each box indicate the minimum and maximum values, while the 688 box is defined by the lower and upper quartiles and the mean value. 